Pål Kolstø and Helge Blakkisrud. Living with Non-recognition: State- and Nation-building in South Caucasian Quasi-states.

This article is published in

Europe-Asia Studies. 2008, vol 60(3), pp 483-509.

Published in DUO with permission from Taylor\&Francis.

The final, definitive version of this of this article has been published in Europe-Asia Studies.

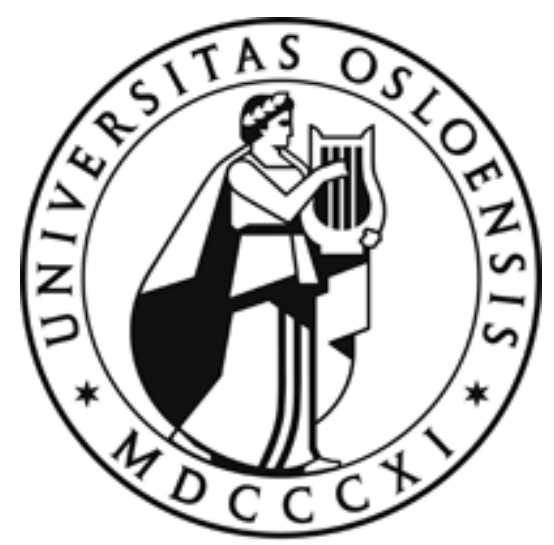




\section{Living with Non-recognition: State- and Nation-building in South Caucasian Quasi- states}

\section{PÅL KOLST $\varnothing$ \& HELGE BLAKKISRUD}

THE COLLAPSE OF THE SOVIET UNION DID NOT RESULT in an all-out conflagration, as some had feared, but it did lead to several small and medium-sized wars on the periphery. In one of these wars - in Tajikistan between 1991 and 1993-the issue at stake was control over one of the emerging post-Soviet states; most of the others, however, concerned secession from one of the fledgling states. This was the case in Chechnya, Pridnestrovie, Abkhazia and South Ossetia. A third type of conflict involved war between two post-Soviet states, like that between Armenia and Azerbaijan. Also here, however, secession was at the centre of the dispute, as the two states were fighting for control over the Nagorno-Karabakh Autonomous Oblast', which wanted to secede from Azerbaijan.

Five of these conflicts ended in the establishment of a non-recognised quasi-state that controlled all or most of the disputed territory.1 While the secessionist regime in Chechnya subsequently lost control over the territory to which it laid claim, four other quasi-states still exist in the territory of the former Soviet Union: the Pridnestrovskaya

We would like to thank Svante Cornell for extensive comments on a previous version of this article. 1There is no established consensus in the scholarly literature on the most appropriate appellation for these political entities. Some authors use the terms 'unrecognised states' (King 2001) and 'de facto states' (Pegg 1998), while others prefer 'pseudo-states' (Kolossov \& O'Loughlin 1999), 'para-states' or 'quasi-states' (Baev 1998). In accordance with the terminology established by Kolstø (2006), we will in this article use the term 'quasi-states'. 
Moldovskaya Respublika in Moldova (PMR); the Republic of Abkhazia and the Republic of South Ossetia, both in Georgia; and the Republic of NagornoKarabakh (NKR) in Azerbaijan. On 2 September 2006, the Republic of NagornoKarabakh celebrated its fifteenth anniversary as a separate state with the presence of, among others, visiting guests from the other three unrecognised states. 2 Few other state leaders, however, bothered to come. Recognised states and unrecognised states do not play together.

In this article we will set aside the thorny legal and moral issues of whether the victors of the post-Soviet secessionist wars ought to be rewarded with international recognition. 3 Instead, we focus on whether the three quasi-states of the South Caucasus may be said to exist as functioning state entities.4 To what extent are the authorities able to provide the populace with the services expected of contemporary states, such as internal and external security, basic infrastructure, and welfare? Next, we note that all these putative states go one step further in their claims: they insist that they are not merely functioning states, but indeed nation-states that command the loyalty and allegiance of their population. We will thus discuss not only whether these quasi-states may be said to possess real 'stateness', but also their claim to embody real nationhood.5

In accordance with the terminology we have used in earlier studies (Kolstø 2000; Kolstø \& Blakkisrud 2004, pp. 8 - 10), we define state-building as the establishment of the administrative, economic, and military groundwork of functional states. It includes the establishment of frontier control, securing a monopoly of coercive powers on the state territory, and putting into place a system for the collection of taxes and tolls. These are the 'hard' aspects of state construction, as it were. By contrast, nationbuilding concerns the 'softer' aspects of state consolidation, such as the construction of a shared identity and a sense of unity in a state's population, through education, propaganda, ideology, and state symbols. Such 'nation-building' is a process actively pursued by state leaders, intellectuals, educators, and others who try to give a state the qualities of a nation-state. Nation-building is intended to instil in the population a sense of being one common nation, to cultivate a sense of belonging to the particular state in which they live and no other. Very often this policy includes elements of cultural and linguistic homogenisation, as well as popular participation in political institutions and processes.

In the modern world, statehood and nationhood are intimately related. If the citizens identify with the state they live in it will be much easier to get them to defend it ${ }_{2}$ NKR is the oldest of the South Caucasian quasi-states. South Ossetia formally declared its independence on 29 May 1992 and Abkhazia on 23 July 1992.

3For such discussions, see e.g. Public International Law and Policy Group (2000), Potier (2001), Bahcheli et al. (2004), and Baran and de Waal (2006).

4The fourth remaining post-Soviet quasi-state, PMR, is discussed in Kolstø et al. (1993) and Kolstø and Malgin (1998).

$5 \mathrm{An}$ interesting aspect of the existence of quasi-states is the role played by patron states. These are, in most cases, crucial for the very emergence as well as the continued survival of the quasi-states. As we want to focus on how the processes of state-building and nation-building are being implemented within the quasi-states, a discussion of the role of the quasi-state in the policies of the patron state (e.g. the role of Abkhazia in Russia's policy towards Georgia) nevertheless falls outside the scope of this article. 
in times of war and crises, to make them pay their taxes, and in general to contribute to the common weal. Conversely, the populace will be far more prone to attach their identity and loyalty to the state if they feel that they get something in return-in security and other benefits and goods. In this article, then, we treat nationhood not as a normative term but as a quality that strengthens the quasi-states' chances for survival. In the following, we present a comparative analysis of the above-mentioned aspects of state-building and nation-building in the South Caucasian quasi-states. Under the heading of 'state-building' we first look at the quasi-state's capacity for defence and control over borders and territory, and next, at economic performance as an indicator of the state's ability to provide welfare and infrastructure. Under the caption 'nation-building' we discuss nationhood in terms of both demos and ethnos. By this we mean that the inhabitants of a state can identify with it both through participation in democratic, political processes, and through a feeling of cultural and ethnic belonging. The policies adopted by the quasi-states may serve to strengthen or weaken either of those aspects. First, however, we discuss the historical background to the secessionist conflicts.

\section{The historical roots}

\section{Abkhazia}

In the early nineteenth century, the Russian Empire began penetrating the current territory of Abkhazia, which was then under Ottoman rule. Present-day Sukhumi was subjugated in 1810, and the rest of the territory was acquired in piecemeal fashion over the next few decades. Not until 1864, however, did the Russians depose the local Shervashidze dynasty and abolish the internal autonomy of the principality. After the 1917 Revolution, the Abkhaz people again regained autonomy, this time in the form of a union republic within the new Soviet Union. In 1931, however, Abkhazia found itself demoted to the status of an autonomous republic and incorporated in the Georgian Union Republic, a status it was to retain until the break-up of the Soviet Union.6

The ethnic Abkhaz speak a language belonging to the northwest Caucasian language family. They adopted Christianity at an early stage, but quite a few were converted to Islam during Ottoman rule. Most Muslim Abkhaz were forced to migrate to Turkey in the late nineteenth century. Even so, according to the 1886 census the Abkhaz still made up $85 \%$ of the population of the region. 7 However, as a result of an active Soviet migration policy, by the last Soviet census (1989) the Abkhaz proportion of the population had diminished to a mere $17.8 \%$ while the Georgian share had risen to $45.7 \%$. Other important ethnic minorities were the Armenians (14.6\%), Russians

${ }_{6}$ For a thorough, albeit clearly pro-Abkhaz, version of Abkhaz history, see Hewitt (1999). A more balanced presentation is given in Coppieters et al. (1998).

7This figure is disputed, as it includes the so-called samurzakans. Other sources give a lower share of Abkhaz. According to www.ethno-kavkaz.narod.ru/rnabkhazia.html (accessed 3 November 2007), the Abkhaz constituted only $27.8 \%$ of the population in 1926 . 
(14.3\%), and Greeks (2.8\%) (Natsional'nyi sostav 1991). The total population of Abkhazia at the time of this census was 525,000.

Discriminatory policy during the Stalin years, demographic pressure, and not least the potential prospect of Georgian secession from the Soviet Union, fuelled Abkhaz nationalism during the perestroika years. In February 1992, the Georgian authorities restored the 1921 pre-Soviet Constitution. In Abkhazia this was perceived as an attack on Abkhazia's autonomous status. In response, on 23 July 1992 the Abkhaz authorities declared independence. 8 The Georgian authorities dispatched troops to restore order and the Abkhaz forces were pushed back. Soon, however, the Abkhaz troops were reinforced by numerous volunteers from Russia (in particular from the Confederation of Mountain Peoples of the Caucasus). In September 1993, Sukhumi was recaptured, and the Georgian forces were put on the defensive. Most of the ethnic Georgian population fled the republic with the retreating army. In December 1993, a ceasefire agreement was signed, and the Abkhaz authorities began building a state and a nation out of their still-unrecognised republic.

\section{Nagorno-Karabakh}

The Republic of Nagorno-Karabakh (NKR)—or Artsakh, as the region is often called by the local Armenian population-is geographically based on the autonomous oblast' established by the Soviet authorities in 1923. From the fourteenth century onwards, Karabakh, although formally a part of the Ganja Khanate, was ruled by the local Armenian aristocracy (meliks), who enjoyed wide autonomy under the Persian Safavid dynasty. Russian rule in Karabakh was introduced in 1805. With the disintegration of the Russian Empire, Armenia and Azerbaijan repeatedly clashed over the region, but as the Bolsheviks re-established control over the South Caucasus, the question was decided by Moscow: in 1923, the Soviet authorities established the NagornoKarabakh Autonomous Oblast' within the Azerbaijani Union Republic. 9 Nagorno-Karabakh has traditionally been populated by two ethnic groups, the Christian Apostolic Armenians (speaking a language that constitutes a separate subbranch of the Indo-European family) and the Muslim, Turkic-speaking Azeris. The relative balance between these groups throughout history is disputed. While Armenians claim a strong historic presence in Nagorno-Karabakh, Azeri historians say that the region was predominantly Muslim until the nineteenth century, when the Russian Empire settled Armenian immigrants from the Ottoman Empire and Persia in Nagorno-Karabakh. The first Soviet census, conducted three years after the oblast' had been established, showed that $89.1 \%$ of the population was Armenian and $10.1 \%$ Azeri. Throughout the Soviet period, the proportion of Armenians gradually declined

8 With reference to Georgia's reintroduction of the 1921 Constitution, the Abkhaz authorities restored their 1925 Constitution. According to the latter, Abkhazia and Georgia were equal partners under a common union superstructure.

9The historical writing of Nagorno-Karabakh has, as in the case of the other South Caucasian quasistates, been highly politicised. Armenian and Azeri historians have widely differing interpretations of how far the region displayed Armenian or Azeri characteristics. For an account of the history of the Armenian population in the South Caucasus, including Nagorno-Karabakh, see Herzig and Kurkchiyan (2005). 
to $76.9 \%$ by 1989 , whereas the Azeri share had more than doubled, to $21.5 \%$ by 1989

(Natsional'nyi sostav 1991). In the late Soviet period, the total population of the oblast' stood at 189,000.

In the late 1980s, the Karabakh question became a major issue not only in the region itself, but also in the Armenian Union Republic. On 20 February 1988, Armenian deputies in the Nagorno-Karabakh oblast' Soviet voted in favour of a merger with the Armenian Union republic. Clashes both in Nagorno-Karabakh and Azerbaijan proper followed (most notably the Sumgait pogrom), resulting in a mass exodus of Armenians from Azerbaijan and Azeris from Armenia. In January 1990, the Soviet authorities responded by dissolving the oblast' Soviet and placing NagornoKarabakh under the direct control of Moscow. This did not, however, redress the grievances of the Karabakhi Armenians, and on 2 September 1991, oblast' authorities declared the establishment of the Republic of Nagorno-Karabakh.10 On 21 November 1991, with the Soviet Union falling apart, Baku rescinded Nagorno-Karabakh's autonomy. Stepanakert (now officially renamed Khankendi by the Azerbaijani authorities) responded on 10 December 1991 with a referendum in which the Armenian population voted 'yes' to independence. The referendum was boycotted by the Azeri minority. In the following months, communal clashes developed into a bloody civil war. Even though the Azerbaijani side initially commanded more men and heavy weaponry, the Armenians beat back the attacks and even conquered vast tracts of undisputedly Azerbaijani territory before a ceasefire was concluded in May 1994, turning the war into a 'frozen conflict'.

\section{South Ossetia}

As regards the current South Ossetian quasi-state, it has its immediate historic roots in the South Ossetian Autonomous oblast' that was set up by the Soviet authorities in 1922 to cater for the political and cultural needs of those Ossetians who lived in the southern foothills of the Caucasus mountains. The Ossetians are predominantly Christian and speak a language belonging to the Iranian group within the larger IndoEuropean language family. Toward the end of the Soviet period, no more than $10.9 \%$ of the almost 600,000 Ossetians in the Soviet Union were living in the South Ossetian Autonomous oblast', whereas a full $56 \%$ lived in the adjacent North Ossetian Autonomous Republic. By 1989, there were more Ossetians in Georgia living outside their titular territory $(99,000)$ than within the oblast' $(65,000)$. The oblast' itself included several Georgian and mixed Ossetian - Georgian villages, especially in the Tskhinvali region and the eastern part of the territory. According to the 1989 census, Ossetians made up 66\%, Georgians 29\% and Russians 2\% of the population (Natsional'nyi sostav 1991).

The level of interaction and intermarriage between Ossetians and Georgians was relatively high throughout most of the Soviet period. The national euphoria that swept the Soviet Union in the late 1980s, however, sparked new tensions. In November 1989,

10In the meantime, control over Nagorno-Karabakh had been returned to Azerbaijan, adding fuel to the fire. For a more detailed account of the perestroika years and the eruption of the conflict, see e.g. de Waal (2003) and Cornell (2000). 


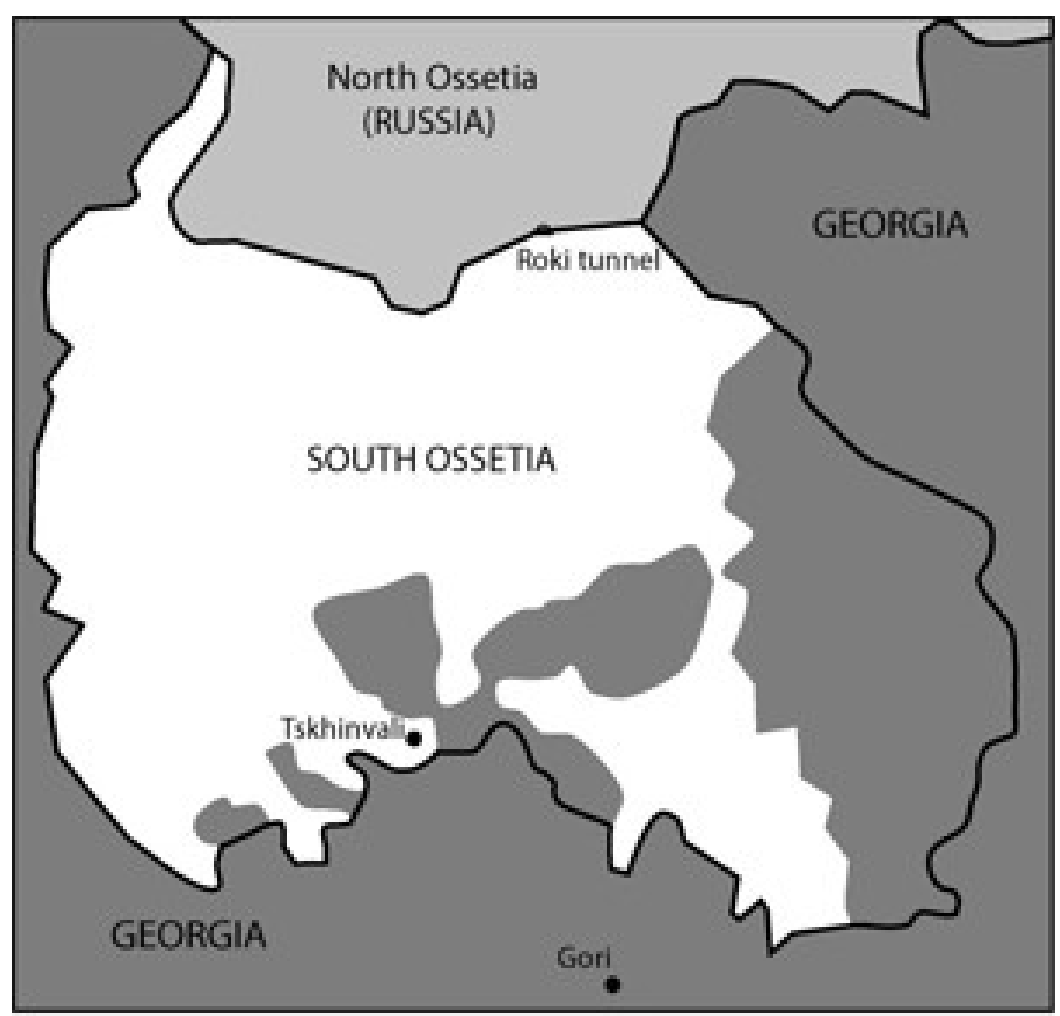

\section{Legend:}

Areas under control

of Tskhinvali

Areas under control

of Tbilisi

FIGURE 1. MAP SHOWING SOUTH OSSETIA
- Border of former South Ossetian
Autonomous Oblast

as Georgia was gradually pulling away from the Soviet Union, the oblast' authorities decided to unilaterally declare South Ossetia an autonomous republic and to unite with North Ossetia. The Georgian authorities declared this move unconstitutional; later the same month, the first clashes between Ossetians and Georgians took place in Tskhinvali. In September 1990, the South Ossetian parliament adopted a declaration on sovereignty and on republican status. Having boycotted the Georgian elections in October,11 Tskhinvali organised its own parliamentary elections in December. The response from Tbilisi was harsh: on 11 December, South Ossetian autonomy was abolished, and in early January 1991 national-guard and police units were dispatched to the breakaway region to restore order. This led to a protracted secessionist war that lasted until June 1992. On 29 May 1992, shortly before the ceasefire agreement was signed, the South Ossetian parliament adopted a declaration of independence and a new post-Soviet quasistate came into being.

\section{State-building: defence and control over borders and territory}

The most fundamental aspect of state-building involves establishing physical control over the territory of the state-to-be. Abkhazia won the war in 1993, but still lacks control over parts of the territory to which it lays claim. The Kodori Gorge in northeastern Abkhazia has not been under Abkhaz control since the war, although Georgian control has been precarious as well. Instead, the local Svans under the 
leadership of warlord Emzar Kvitsani more or less ruled themselves for several years without interference from Tbilisi, aided by a 'gentlemen's agreement' with Sukhumi that the Svans would stay out of the Abkhaz - Georgian conflict (Chamagua 2006). All this changed after the Rose Revolution and Mikheil Saakashvili's accession to power in Tbilisi in 2003. In September 2006, heavily equipped Georgian police and security forces entered the Kodori Gorge and swiftly defeated Kvitsani's paramilitary forces. Later that autumn, in an open challenge to Sukhumi, the Georgian-backed Abkhaz government-in-exile relocated from Tbilisi to the gorge.12 In Sukhumi, fears arose that this might be 'a test balloon' prior to an all-out Georgian attempt to recapture Abkhazia by force (Zayavlenie 2006). When interviewed in September 2006, Stanislav Lakoba, Secretary of the Abkhaz Security Council, saw the situation as very complicated: neither war, not peace. Young people, he observed, were increasingly acquiring a 'siege mentality'. This was not a development that the Abkhaz authorities wanted or encouraged—quite the contrary, he averred.13

Besides Kodori, which is now completely outside Abkhaz control, the power of the Abkhaz state is tenuous in the Gali region in the southeast. The Gali region is inhabited mostly by ethnic Mingrelians (or simply 'Georgians', as the Georgian

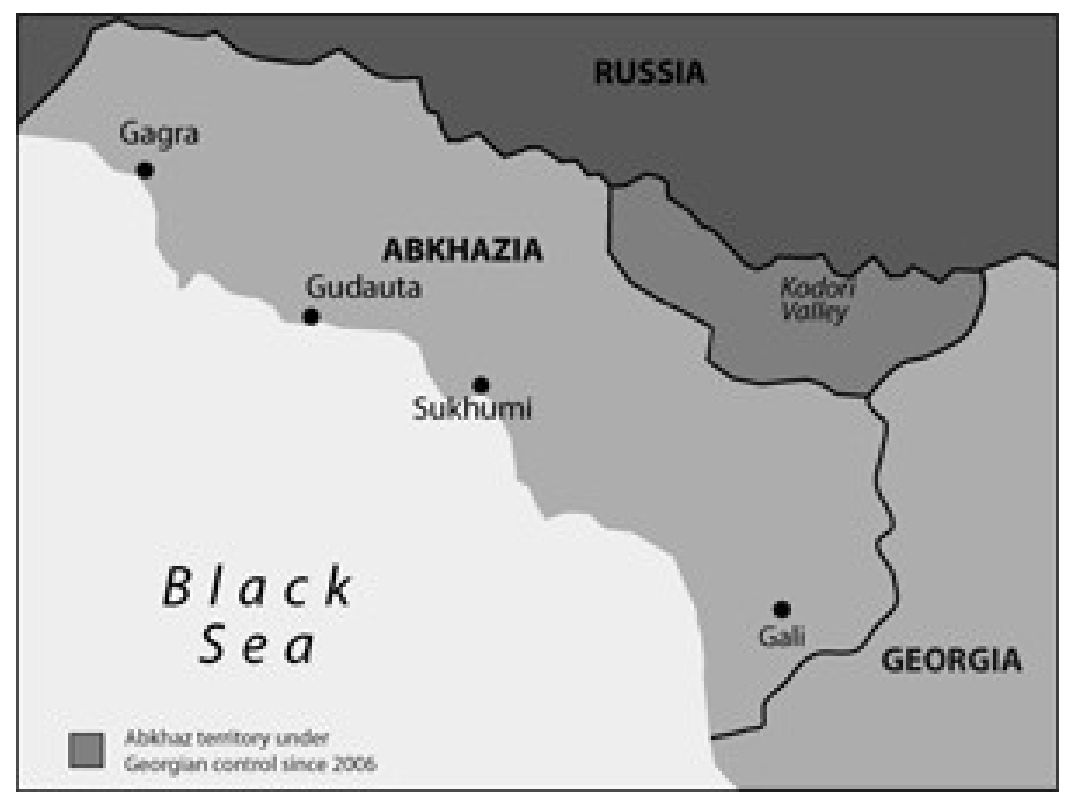

FIGURE 2. MAP SHOWING ABKHAZIA

12The government-in-exile is based on the old council of ministers that was evacuated to Tbilisi in 1994. It now operates out of the village of Chkalta in the Kodori Gorge and controls approximately $17 \%$ of the territory of the pre-war republic.

13Authors' interview, Sukhumi, 7 September 2006. 
authorities would have it). Many Mingrelians who fled to Georgia during the 1992 1993 war later returned. The Abkhaz authorities claim that non-local Georgians as well as agents of the Georgian security apparatus followed in their wake. In April May 1998 they conducted a clean-up operation directed against the paramilitary groups the White Legion and the Forest Brethren, an operation that caused many of the returnees to flee once again. As in Kodori, the border zone in Gali has been patrolled since 1994 by an entirely Russian peacekeeping force of CIS peacekeepers, and United Nations Observer Mission to Georgia (UNOMIG) observers. Although the situation in the border zone remains volatile, there is considerable movement of ethnic Mingrelians/Georgians commuting across the border on a daily or seasonal basis.

Unlike the case of Abkhazia, Nagorno-Karabakh (NKR) has control over virtually all the territory the republic lays claim to. The main exception is the Shahumanyan region in the north, which was not part of the Nagorno-Karabakh Autonomous Oblast' in Soviet times, but had a predominantly Armenian population.14 On the other hand, NKR has occupied a huge chunk of undisputedly Azerbaijani territory. This includes the strategically vital Lachin Corridor, a small strip of land that used to separate Nagorno-Karabakh from Armenia, as well as vast territories to the west (Kelbajar), south (Gubadly, Zangilan, Jabrayil and part of Fizuli), and east (the western half of Agdam). Just as in Nagorno-Karabakh proper, the ethnic Azeri population in the occupied areas was forced to flee during the war. Many former Azeri villages and towns now stand uninhabited, but in the Lachin Corridor, the NKR authorities have encouraged Armenians to settle, in order to strengthen territorial control.15 All along the ceasefire line, strong fortification works have been undertaken. There is no traffic whatsoever across the ceasefire line.

The army has a much higher profile and visibility in NKR society than in Abkhazia and South Ossetia. With 15,000 - 20,000 men under arms, the Nagorno-Karabakh Defence Army also has by far the largest army of the three secessionist states.16 In terms of state-building and nation-building this is a double-edged sword. On the one hand, without the army the state would not have existed: it is, as stated in official publications, 'the most basic guarantee for NKR's independence and one of the most important achievements of the Artsakh liberation struggle' (Nagorno-Karabakhskaya 2006, p. 41). On the other hand, there is also the risk that the army might get out of control and threaten the development towards democracy and a state governed by the rule of law. A case in point is the story of war hero, Defence Minister and Commander-in-Chief Samvel Babayan, who rose to prominence during the independence struggle. After the war, Babayan was granted considerable power and

14The Armenian population fled during the war, and the region now forms a part of the Azerbaijani Goranboy region.

${ }_{15}$ Settlers are offered cattle, building subsidies, subsidised utilities and tax breaks by the NKR government.

16Moreover, unlike the other secessionist armies, the NK army is well-integrated with a regular army (the Armenian), which is a great advantage when it comes to purchasing military materiel. A telling example of the close integration is the fact that the Nagorno-Karabakh Minister of Defence Serzh Sargsyan later took up the same post in the Armenian government before moving on to become Prime Minister of Armenia in 2007. 


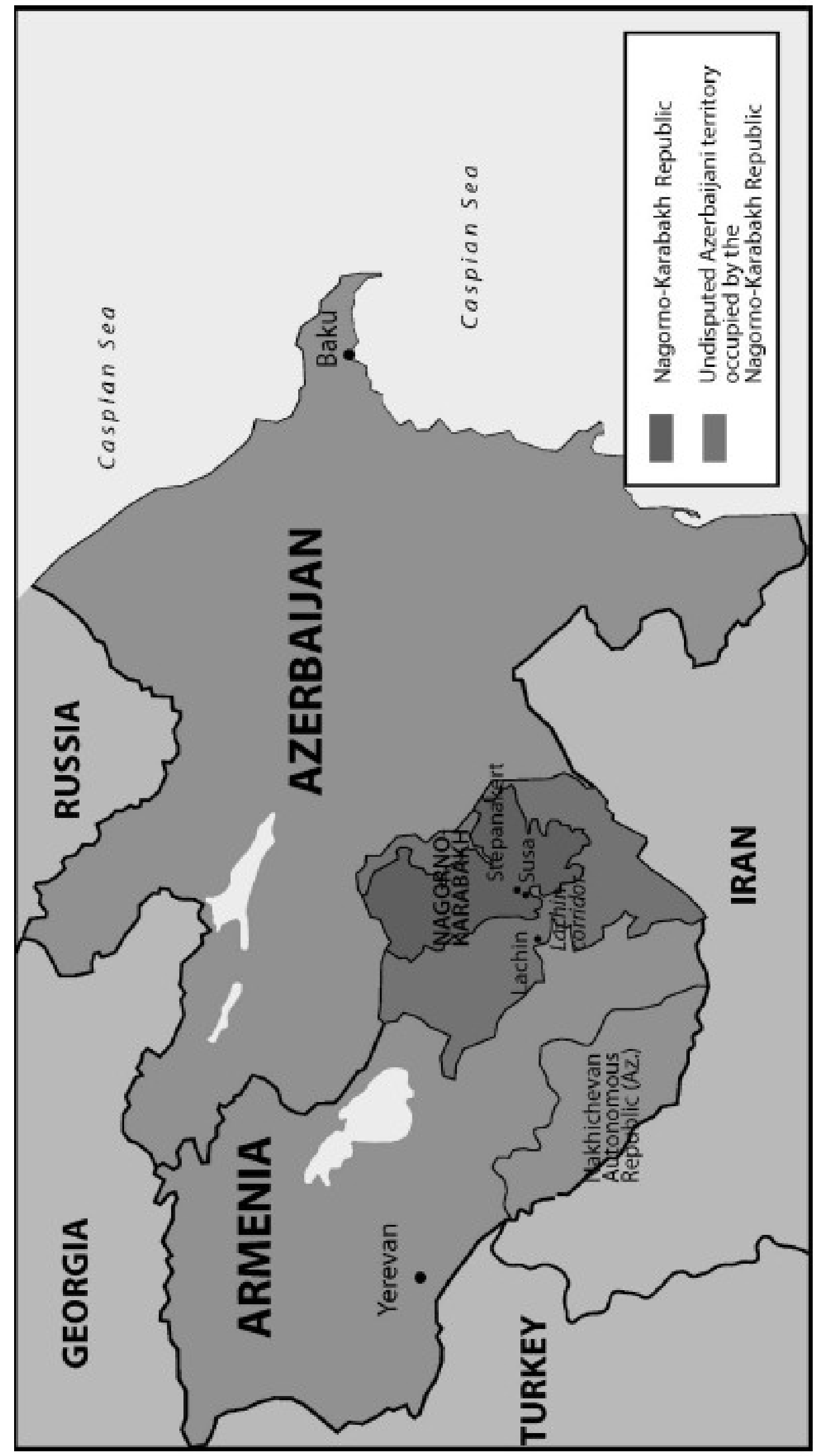


autonomy within the sphere of security, with little or no supervision from the civilian authorities. Babaian used his strongman position to acquire control over many of the most profitable businesses in NKR as well as to obtain tax and customs privileges. With President Robert Kocharian's departure from Stepanakert in 1997 (see below), Babaian increasingly began to assert influence over the government, until in 2000 he was finally ousted. With the backing of Yerevan, he was arrested, accused of an assassination attempt on the NKR president, and sentenced to 14 years in prison. In the case of South Ossetia, Tskhinvali controls about $80-85 \%$ of the towns and villages of the former South Ossetian Autonomous Oblast', according to Foreign Minister Murat Dzhioev.17 The remainder consists of mostly Georgian-inhabited villages in the south and east. The current demarcation line between South Ossetia and Georgia basically reflects the complex ethnic population pattern and follows a highly intricate course (although a few ethnically Ossetian villages are located on the Georgian controlled side of the border). Some Georgian settlements are virtually surrounded by South Ossetian territory, and vice versa. This also means that the border is extremely difficult to defend.18 Since the cessation of hostilities in 1992, the border zone has been patrolled by a peacekeeping force consisting of Ossetian, Russian and Georgian units, and the border regime is monitored by the Organization for Security and Co-operation in Europe (OSCE) Mission to Georgia.

In sharp contrast to the situation in Nagorno-Karabakh, the border between South Ossetia and Georgia remained quite permeable throughout much of the post-Soviet period, with people moving back and forth relatively freely. Tskhinvali residents could go shopping in Gori, the closest city on the Georgian side; Georgians could visit relatives in South Ossetia. These contacts meant that tensions remained generally low, and in the 1990s the South Ossetian conflict was regarded as being 'close to solution'in sharp contrast to the two other conflicts discussed here (Malysheva 1996, p. 35). Georgian President Eduard Shevardnadze and South Ossetian President Lyudvig Chibirov met several times, and many practical and economic problems were sorted out in this period. For example, cooperation between Georgian and South Ossetian police was improved.19

Since the toppling of Shevardnadze in 2003, however, the situation has changed dramatically. From being the most tranquil of the disputed regions, the Georgian - South Ossetian border has become the most volatile. The June 2004 closing of the market at the Ergneti border-crossing was followed by a sharp escalation of the conflict, including shelling of Tskhinvali as well as Georgian villages. Although a bilateral agreement on demilitarisation of the border was signed in November 2004, frequent night-time shootings and shelling from both sides have been common ever since. The South Ossetian authorities see this as a result of a new aggressive Georgian nationalism under Saakashvili. Bellicose statements from Georgian official representatives, such as Defence Minister Irakli Okruashvili's infamous pledge to celebrate the

17Authors' interview, Tskhinvali, 15 September 2006.

${ }_{18}$ For an excellent detailed map of the ethnic composition of South Ossetian villages, see Bartuzi

(2006). Territorial control was further aggravated in 2006 by the establishment of a rival presidency in the Georgian-controlled sector (see below).

19Authors' interview with Foreign Minister Murat Dzhioev, Tskhinvali, 15 September 2006. 
New Year in Tskhinvali in January 2007 (Anjaparidze 2006), have done little to allay such fears.

As for internal control over territory, the government has only gradually been able to assert its authority. In the aftermath of the 1991 - 1992 war, former combatants showed little respect for the law or for civilian authorities. Clan structures, most notably the Tedeev brothers, challenged-and interacted with—state structures. In recent years, however, the situation is said to have improved.20

Economy and social conditions

The second aspect of state-building that we want to explore is the ability of the quasistate to collect taxes and tolls and to provide social security for its population. The war of 1992 - 1993 left Abkhazia thoroughly devastated. This is a fact not only acknowledged by the Abkhaz authorities but also actively used in propaganda:

During the Soviet times, Abkhazia was one of the most prosperous regions of the former Soviet Union. . . Today, the country produces a grim picture. The lush nature cannot conceal burned and destroyed houses, schools and kindergartens, looted factories, blown-up bridges, roads and tunnels. The majority of the enterprises are at a standstill now. Many plants are destroyed. For the rest, there are no supplies of raw materials, and no cash to pay the workers' salaries ... The Gross Domestic Product (GDP) in 1994 was US $\$ 60.3 \mathrm{mln}$, which, compared with $692.5 \mathrm{mln}$ in 1988 , makes up only $14 \%$ of the prewar level. (Chirikba nd)

The blame for this is put on Georgian looting and wanton destruction during the war-in other words, the misery is not seen as reflecting Abkhaz state-building capacity as such. The description nevertheless gives rise to the question of how this situation can be squared with the claim that Abkhazia is already a functioning state. The source of the quotation above-a text posted on the Internet in the mid-1990spresents the viability of the Abkhaz state in terms of future prospects and possibilities: Given its natural wealth, important strategic position, and active and enterprising population, one can positively assess the perspectives for dynamic economic development. The numerous Abkhazian diaspora communities all over the world will undoubtedly also contribute to the economic recovery and prosperity of Abkhazia. (Chirikba nd) How does this look from the vantage point of 2007 ? The Russian economic blocade imposed in December 1994 (on Georgian insistence) was lifted in 1999, and the economy is clearly recovering, although slowly.21 While the state budget in 2004 was no more than R447 million, or $e 13$ million (Zakon 2004, p. 52), it has more than doubled over the past three years to R1.2 billion (e 35 million) in 2007.22 This is still, of course, extraordinarily small. The government has embarked upon structural reforms. The necessary legislation has been adopted to enable privatisation of small and medium-sized firms, whereas larger firms have been privatised in a more ad hoc

20Authors' interview with independent journalist Inga Kochieva, correspondent of Kavkazskii uzel, Tskhinvali, 15 September 2006.

$21 \mathrm{~A} \mathrm{CIS} \mathrm{blockade} \mathrm{imposed} \mathrm{in} \mathrm{January} 1996$ is still officially in force.

22Ekonomika, available at: www.apsny.ru/economic/economic.php?, accessed 15 January 2007. 
manner-which has led to accusations of cronyism. Income tax is low, around $10 \%$, and basic communal services are cheap or free.23 A certain negative reciprocity and mutual understanding developed in state - society relations in the first chaotic years after the war: the state does little for the population, and the population does little for the state. These attitudes are only slowly being improved.24 Nevertheless, the overall picture would seem to be one of gradual improvement: 'We started with half a loaf of bread, then one loaf of bread. If the average monthly salary in 1997 was 300 roubles, today it is 10 times as high'.25 However, even R3,000 per month, the equivalent of $e 87$, is still far from sufficient to ensure a decent living. Galust Trapizonian, chairman of the parliamentary committee on social issues, admits that approximately $40 \%$ of the population are living on incomes beneath the official subsistence level (prozhitochnyi minimum).26 For pensioners, the situation is particularly dire: they would have lived in utter destitution had it not been for Russian assistance. According to Deputy Minister of Foreign Affairs Maksim Gvindzhia, roughly $80 \%$ of the population hold dual Abkhaz - Russian citizenship,27 and are therefore also entitled to a Russian pension. In 2006, the minimum pension for Russian citizens was R1,160, as compared to an Abkhaz minimum pension of R100. At the time, some 28,000 Abkhaz pensioners were eligible for this additional Russian pension.28 Having R1,260 and not R100 per month to live on makes all the difference in the world.

This 'solution' to a grave social problem, however, points to a serious problem of statehood. The Abkhaz state is not able to provide its citizens with the preconditions for an adequate livelihood and has to rely on a neigbouring state to provide basic services. This point is indirectly conceded by the Abkhaz authorities themselves. According to Abkhaz Foreign Minister Sergei Shamba, Abkhazia is a 'Russian protectorate', but, he hastens to add, 'just like Georgia is an American protectorate'.29 In any case, Shamba avers, living conditions in Georgia are far worse than in Abkhazia. Those Westerners who visit only Tbilisi may perhaps be led to believe otherwise, but the poverty in Georgian villages, he maintains, is appalling. If Abkhazia is a protectorate of Russia, it is also a dependency of the international community of relief organisations. According to Dov Lynch (2004, p. 84), in the immediate post-war years the contribution of international NGOs like the Red Cross, Me'decins sans frontie'res and others was three times the size of the Abkhaz state budget. Again, while the Abkhaz authorities are extremely appreciative of this help, the situation underscores the status of Abkhazia as a state 'on the dole'. Moreover, the presence of the 'internationals' creates a parallel economy with salaries far above the

23Authors' interview with Finance Minister and Deputy Prime Minister Beslan Kubrava, Sukhumi, 7 September 2006.

24Authors' interview with journalist Nadezhda Venediktova, Sukhumi, 6 September 2006.

25Authors' interview with Abkhaz Foreign Minister Sergei Shamba, Sukhumi, 7 September 2006.

${ }_{26}$ Authors' interview, Sukhumi, 8 September 2006.

27Authors' interview, Sukhumi, 6 September 2006. This figure, if correct, would necessarily include some ethnic Georgians as well.

28Authors' interview with Galust Trapizonian, chairman of the social committee in the Abkhaz

parliament, Sukhumi, 8 September 2006.

29Authors' interview, Sukhumi, 7 September 2006. 
average. The Red Cross pays its local employees in Abkhazia twice as much as they would earn in a comparable job outside the international sector, while those working for the UN earn up to four or five times as much.30

The government is thus still not able to fulfil its obligations toward the population without relying heavily on external support and infrastructure, first and foremost from Russia. A particularly serious problem is posed by the reluctance of Abkhaz students who study abroad to return home afterwards. Of some 600 young people who have completed their studies in Russia in recent years, only $27 \%$ have returned. The Abkhaz authorities try to appeal to their sense of duty to the fatherland, but the students complain about low salaries and the impossibility of finding jobs for which they are qualified. Sometimes, they claim, the jobs they might want are given to less qualified people with the right family connections. To combat this difficulty, the Abkhaz authorities have threatened to instruct Russian educational institutions that accept Abkhaz students not to provide a graduation diploma unless they return home (Shul'gina 2006). This tactic may help in the short run but will be self-defeating in the long run, as it undercuts the very patriotism to which the Abkhaz state otherwise seeks to appeal. In Nagorno-Karabakh the war lasted longer and took a heavier toll of lives than the wars in Abkhazia and South Ossetia.31 Material damage in many towns and villages was enormous (de Waal 2003), but reconstruction has been extensive. Whereas in central Sukhumi many buildings are still standing as empty shells, downtown Stepanakert is today almost completely rebuilt. Remote villages, however, often present a far bleaker picture. Much of the credit for the more rapid recovery in Nagorno-Karabakh goes to the Armenian diaspora, which has contributed substantial help, not least in infrastructure. The old road between Nagorno-Karabakh and Goris in Armenia, Nagorno-Karabakh's lifeline, has received very substantial repairs and improvements in recent years, making it one of the best roads in the region. It symbolically links together not only Nagorno-Karabakh and Armenia but also Nagorno-Karabakh and the diaspora, as signs along the road tell which sector has been sponsored by which donors.32 In fact, this is much more than symbolism: after the closure of Stepanakert airport in 1990, this road has become the sole link between Nagorno-Karabakh and the outside world. While the Nagorno-Karabakhi authorities readily acknowledge the crucial contribution of the diaspora in the republic's economy, they also underscore the role played by their own economic policy. NKR opted early on for privatisation, price liberalisation, and a general transition to a market economy. Today all small and medium-size enterprises have been privatised, and the privatisation of larger enterprises continues. Investors pay only $5 \%$ tax on profit, and foreign investment

$30 \mathrm{~A}$ third potential source of economic relief for Abkhazia is, as pointed out by Chirikba above, the ethnic Abkhaz diaspora in Turkey. During the blockade in the 1990s Turkey looked the other way while its citizens, primarily those with Abkhaz ethnic roots, provided aid and trade to the quasi-state. The once-high hopes for a vigorous resuscitation of links with the diaspora have nevertheless been in vain (Ivanova 2006).

31 The exact number of casualties is disputed, but most sources place the figure in the range of $25,000-30,000$.

32Likewise, the diaspora has funded the construction of the new 1,700-km-long North - South 'Backbone' Highway. 
is encouraged.33 Initially, the privatisation programme encountered numerous difficulties, especially with the privatisation of land (Ayrapetyan 2006, p. 83), but the policy has nevertheless paid off. Diaspora Armenians have invested both in the labour-intensive carpet industry and the large Drmbon gold and copper mine, which was reopened in 2003 . The government has also been able to curb the initially high inflation and has achieved macro-economic stabilisation.

NKR had a serious problem with its shadow economy in the first years after independence. The rampant smuggling that has developed into a cornerstone enterprise in many other non-recognised states has, however, had no chance to develop in NKR, for a very practical reason.34 Geographically, NKR is at a dead end, and the smuggling routes from Iran to Russia bypass it. This has contributed to a more healthy development of the NKR economy. Moreover, international relief organisations have played a far more modest role in NKR than in Abkhazia. Their more active engagement might have speeded up the recovery process, but as a result of their absence NKR has arguably avoided some of the clientelistic attitudes evident in parts of Abkhaz society. Armenia, as well as the diaspora in general, may, however, fulfil the same role of a benevolent and generous donor, with inter-Armenian help substituting for the role of the international community.35 Each year, NKR receives a huge interstate loan from Armenia, in 2006 to the tune of 28 billion dram (the equivalent of ${ }_{e} 59.3$ million). 36 NKR officials nevertheless deny that they are living on the mercy of Armenia. They pay various direct and indirect taxes to Yerevan, and the difference between what they receive and what they give back is said to be not very great.37 In any case, this arrangement clearly demonstrates the close integration of NKR into the economy and budgetary structures of Armenia. Since 2000 the state budget has increased by roughly $12 \%$ per year, and of this, $44 \%$ goes to the social sector (health, education and social security).38 The official subsistence level is set at 23,000 dram (e 49). One civil-society activist in Stepanakert estimated that around $40 \%$ of the population are living on less than that. The local minimum pension is the equivalent of $e 23$, which is certainly inadequate.

The fighting in South Ossetia during the 1991 - 1992 war for independence was less severe than in the other two quasi-states examined here, and the material damage less extensive.39 Even so, Tskhinvali today looks more rundown than Sukhumi and

33According to Deputy Foreign Minister Masis Mayilyan, the NKR authorities have tried to compensate for drawbacks like difficult communications and lack of international recognition by introducing investment-friendly legislation (authors' interview, Stepanakert, 12 September 2006).

34 In Kolstø (2006, p. 752), it was stated: 'In the NKR the inhabitants eke out a living by smuggling, drug traffic, and selling timber to Iran and other countries'. However, this assertion has not been proven and may have been based on insufficient and slanted information. 35Authors' interview with Davit Babayan, professor of political science at Artsakh State University, Stepanakert, 12 September 2006. 36 Whereas the annual loan is growing year by year, its relative share of the state budget is nevertheless decreasing.

37Authors' interview with Deputy Prime Minister Ararat A. Danielyan, Stepanakert, 12 September 2006.

${ }_{38}$ Authors' interview with Deputy Prime Minister Ararat A. Danielyan, Stepanakert, 12 September

2006.

39Although estimates vary, most sources give a figure of slightly more than 1,000 casualties. 
certainly more so than Stepanakert, but this is due more to lack of maintenance than lack of reconstruction. The townscape clearly reflects the poor state of the South Ossetian economy. Industry in the republic was designed for the Soviet market and when that collapsed most factories had to close. Unlike the situation in Abkhazia and in Nagorno-Karabakh, however, the authorities have been more reluctant to embark upon structural reform. No full-scale privatisation of the economy has taken place. The reason is said to be that the Ossetians do not want to sell their resources for a pittance, and as long as their state is not recognised, any bids at privatisation auctions are bound to be low.40

Another reason why the South Ossetians have been less inclined towards reform may be the huge profits made on transit trade from Russia to Georgia.41 There are only two roads across the mountains between these two countries, and the best one passes through South Ossetia.42 The Georgian side has regarded this business as smuggling. South Ossetian spokespersons, however, deny this charge on the grounds that customs are paid to both Russia and South Ossetia.43 In any case, Georgia allowed this trade for a long time without interfering and a huge market operated at the Ergneti border crossing. In 2004, however, the Georgian authorities, inspired by the success in reintegrating the semi-independent Ajara region, decided to step up the pressure on South Ossetia, and closed down this mainstay of the local economy. Despite this setback, Tskhinvali mayor Vadim Tskhovrebov could inform us that the city budget has grown 10 times over the past three or four years.44 Salaries are said to have doubled-according to Prime Minister Yurii Morozov, reaching an average of R2,500 by 2006 (KliP 2006). Few indicators of macro-economic performance are available, however, and detailed information about the budget is claimed to be for official use only.45 Some spokespersons of the South Ossetian republic are quite optimistic in their assessment of the economic situation. Foreign Minister Murat Dzhioev claims that the economy is developing well-in any case, he points out, living standards are higher than in Georgia.46 Nearly all current residents of South Ossetia hold Russian citizenship, which means that the pensioners among them are entitled to Russian pensions. This makes a considerable difference: whereas the local pension is a mere R250,47 Russian pensions are, for several categories, actually higher than the South Ossetian average salary. Nevertheless, independent journalist Inga Kochieva estimates that the vast majority of the population live below the subsistence level.48

40Authors' interview with Tskhinvali Mayor Vadim Tskhovrebov, Tskhinvali, 15 September 2006.

${ }_{41}$ This trade also generated considerable corruption on the Ossetian as well as on the Georgian and Russian sides, and with it, vested interests in the perpetuation of the status quo (Cornell 2003).

${ }_{42}$ North and South Ossetia are linked by the Roki Tunnel, whereas the Verkhnii Lars border crossing on the old 'Georgian Military Road' from Vladikavkaz to Tbilisi is more exposed to harsh winter conditions.

43Authors' interview with Foreign Minister Murat Dzhioev, Tskhinvali, 15 September 2006.

44Authors' interview in Tskhinvali, 15 September 2006.

45Authors' interview with Tskhinvali Mayor Vadim Tskhovrebov, Tskhinvali, 15 September 2006.

46Authors' interview in Tskhinvali, 15 September 2006. The same claim was reiterated in several other interviews in Tskhinvali [see also interview with Prime Minister Yurii Morozov, KliP (2006)].

${ }_{47}$ Conversation with the former director of the South Ossetian pension fund, Tskhinvali, 14 September 2006.

48Authors' interview in Tskhinvali, 15 September 2006. 
Economic hardship is also reflected elsewhere in the social sector: both healthcare and the education system suffer greatly from the lack of investment. The few international organisations operating in South Ossetia deal mainly with refugees and have not contributed significantly to the development of the republic as such.49 As in the case of Abkhazia, South Ossetia has to draw on Russian infrastructure to meet the basic needs of its people.

\section{Nation-building: ethnos and demos}

Under the heading of nation-building, we will, as mentioned above, examine the different quasi-states' policies aimed at strengthening the population's identification with the ethnos (through stimulating the feeling of cultural and ethnic belonging) as well as the demos (through participation in democratic, political processes). In Abkhazia, as in most other post-Soviet states (Kolstø 2000), the nationhood concept incorporates a tension between an ethnic and a civic understanding of the nation. The constitution, on the one hand, states that 'the sovereignty bearer and sole source of authority in the Republic of Abkhazia shall be its people, the citizens of the Republic of Abkhazia' (Article 2) —and yet, the president is required to be an ethnic Abkhaz (Article 49).50 Although in 1989 ethnic Abkhaz did not constitute more than $17 \%$ of the population, they are nevertheless considered the 'stateforming nation' (gosudarstvo-obrazuyushchii narod). 51 In fact, the Abkhaz section of the population has since grown as a result of displacements during the $1992-1993$ war as well as of out-migration, and today the Abkhaz are said to constitute a plurality. According to the census conducted in 2003, the total population stood at $216,000,52$ of which $43.8 \%$ were ethnic Abkhaz. The other main ethnic groups were the Armenians (20.8\%), the Mingrelians/Georgians (21.3\%), and the Russians (10.8\%).53 The question of how many Mingrelians/Georgians currently reside in Abkhazia is highly politicised. In 2006, the Abkhaz authorities claimed that about 70,000 of the 240,000-strong pre-war Mingrelian/Georgian community had returned to Abkhazia (Fuller 2006), a figure that the Georgian authorities strongly contest.

Except for the Mingrelians/Georgians, most members of the non-titular groups accept the leading role of the Abkhaz in Abkhazia. Although schools offering instruction in a non-titular language have received only limited support, this is not

49Authors' interview with Foreign Minister Murat Dzhioev, Tskhinvali, 15 September 2006.

50Konstitutsiya Respubliki Abkhaziya, available at: www.apsny.ru/republic/republic.php?page $1 / 4$ content/constitution/constitution.htm, accessed 10 January 2007.

${ }_{51}$ Authors' interview with Astamur Tania, advisor to former President Vladislav Ardzinba,

Sukhumi, 7 September 2006.

52The results of the census are available at: www.ethno-kavkaz.narod.ru/rnabkhazia.html, accessed

3 November 2007. The census data include the 2,000 inhabitants of the Upper Kodori Gorge, a territory the Abkhaz government does not control.

53The results of the census are disputed. If correct, the number of ethnic Abkhaz, despite warfare and out-migration, has risen from 93,300 in 1989 to 94,600 in 2003. Some Abkhaz sources are, however, even more optimistic: e.g. the apsny.ru information agency estimates the total population at more than 320,000 in 2001 (available at: www.apsny.ru/republic/republic.php?, accessed 14 February 2007). 
perceived as discrimination, but as a result of the state's general lack of resources.54 There is a certain resentment against the over-representation of ethnic Abkhaz in the state administration — but it is also acknowledged that the Abkhaz have suffered more, both through cultural Georgification in the Soviet period and in the fight for independence. Approximately $70 \%$ of the casualties on the Abkhaz side during the war were ethnic Abkhaz.55 This also indicates that a large number of non-Abkhaz, including $30 \%$ of those who died, were willing to defend Abkhaz statehood by arms. A further indication of non-titular support for Abkhaz statehood may be the 1999 referendum, in which $97.7 \%$ of the voters supported independence (with an $87.6 \%$ turnout). These results must, however, have been 'adjusted' to some extent: not only is the number of registered voters higher than the total population recorded in the census four years later, but the Georgian segment of the population is unlikely to have supported independence-non-titular support for Abkhaz statehood does not in general extend to the Georgians. In fact, the Abkhaz nightmare is that Georgian refugees will come back en masse and overwhelm the Abkhaz state. The Abkhaz authorities send out somewhat mixed signals on the refugee question. Their return is sometimes presented as a matter that might be settled within the framework of an overall peace agreement, but Deputy Foreign Minister Maksim Gvindzhia acknowledges more bluntly that a return of all Georgians is out of the question.56 By post-Soviet standards, Abkhaz democracy is functioning reasonably smoothly. Freedom of the press is good and civil society in Abkhazia is fairly well developed. Oppositional newspapers are perhaps not able to reach out to a large readership, but they operate freely. The party system is not well developed, however. In the most recent parliamentary elections (2007), the pro-presidential bloc, which includes United Abkhazia (Apsny Akzaara), Signal Lights (Amtsakhara) and Revival (Aitaira), secured 28 seats, while the opposition, which is united in the Forum of People's Unity, won seven seats. 57 If a turnover of power is evidence of democracy, Abkhazia can be said to have passed the test. In the presidential elections of October 2004, Prime Minister Raul Khadjimba, the candidate who took up the mantle after the ailing president Vladislav Ardzinba,58 lost to challenger candidate Sergei Bagapsh, even though Khadjimba enjoyed strong backing from Russia. Subsequently, Abkhazia was thrown into a protracted political crisis with public protests, court actions and mutual allegations of electoral fraud. In the end, and after considerable Russian pressure, a compromise was achieved: in January 2005 new elections were held, in which Khadjimba ran as Bagapsh's vice president. This result

54Authors' interview with Suren Kerselyan, leader of the Armenian Community, Sukhumi, 8 September 2006.

55Authors' interview with Liana Kvarchelia, Centre for Humanitarian Programmes, Sukhumi, 7 September 2007.

56Authors' interview, Sukhumi, 6 September 2006.

57The parliament consists of 35 members elected in single-seat constituencies for a five-year term. Elections have so far been held three times: in 1996, 2002 and 2007.

58Ardzinba, a former chairman of the Supreme Soviet of the Abkhaz Autonomous Republic, was elected president in 1994. In 1999, he ran unopposed, but prior to the 2004 elections, his health deteriorated seriously, and Prime Minister Khadjimba became the de facto head of state. 
also showed that, even if it may be a 'protectorate' of Russia, Abkhazia is not always obedient to Russia.

When in our interviews in Sukhumi we tried to probe whether the failure of the Abkhaz state to deliver basic services affects citizens' allegiance, some interviewees at first did not quite understand the question. They saw no immediate connection between welfare and loyalty. The people and the state have common interests against the Georgian aggressors, it was claimed; the people defend the state simply in order to survive. A parallel was drawn with Soviet resistance against the Nazi invasion of the USSR during the Second World War: even after the terrible forced collectivisation of the 1930s, Soviet citizens had defended the Soviet Union ferociously.59 According to Nadezhda Venediktova, Russian journalist and civil society activist, in the war against Georgia people were fighting not so much for the Abkhaz state, as for their country and their kith and kin. During the 1990s the Abkhaz took a civilisational step backward, from a state society to a clan society, in order to survive. On the other hand, that does not mean that they would not take up weapons once again to defend state independence for Abkhazia, if that should be required of them.60 As regards Nagorno-Karabakh, despite the economic hardship and the relative isolation, there has not been a significant drop in the population after the war. Official census figures from 2005 give a population of 137,000 , which is approximately the size of the non-Azeri population of Nagorno-Karabakh Autonomous Oblast' in 1989. Deputy Prime Minister Ararat Danielian has nevertheless admitted the need to design policies to boost fertility rates. As much as $25 \%$ of the population, or 32,000 individuals, are beyond retirement age.61 The NKR authorities also actively encourage immigration, and government spokespersons claim that NKR today is experiencing a positive migration balance. There has been some in-migration from recession-hit Armenian towns and some from the overseas diaspora, but mostly it is a case of Nagorno-Karabakhis who went to Russia to try their luck but, with Moscow tightening its immigration regime, have had to return.

Unlike Abkhazia, Nagorno-Karabakh today has a population that is almost completely homogeneous in ethnic terms. The fact that the entire Azeri pre-war population has fled and lives as internally displaced persons (IDPs) in Azerbaijan may have created a huge obstacle to peace settlement and international recognition, but, cynically speaking, it is an asset in the nation-building process: there are no deep ethnic or religious cleavages among the NKR population today.62 Deep ambiguity clouds the ultimate goal of Nagorno-Karabakhi nation-building, however. On the one hand, it is clearly stated that the foremost aim of NKR foreign policy is to achieve international recognition as an independent state. On the other hand, no claim has ever been made that there exists an independent NagornoKarabakhi nation. On the contrary, the people of NKR are said to be Armenians,

59Authors' interview with Astamur Tania, advisor to former president Vladislav Ardzinba,

Sukhumi, 7 September 2006.

60Authors' interview with Nadezhda Venediktova, Sukhumi, 6 September 2006.

61Authors' interview with Deputy Prime Minister Ararat Danielyan, Stepanakert, 12 September 2006.

62In NKR, the moral, political, and legal issues of the IDP issue is always linked to the question of Armenian refugees from other parts of Azerbaijan to Armenia. 
pure and simple: 'It is impossible to talk about a Karabakhi culture, education, or science as separate phenomena; they are all integral parts of an all-Armenian cultural, educational and scientific system'.63 The Nagorno-Karabakhi experience has been pivotal in transforming the consciousness of Armenians-not only in NKR, but everywhere-from a self-understanding based on victimisation (after the 1918 massacre) to one based on self-defence and victory. Thus, the Nagorno-Karabakhis in a sense do regard themselves as different, but only in a way that links them intimately with the greater Armenian nation: 'Karabakh is the national idea of Armenia'.64 As a result of this ambiguity, NKR has pursued an inconsistent policy of nation-building. Some elements of symbolic nation-building have been promoted, others neglected. There are, for instance, separate NKR postal stamps, but no separate currency; instead, NKR uses Armenian drams. The Nagorno-Karabakh flag reflects this ambiguity. It is a tricolour with the same colours as the Armenian flag, but on the right-hand side a zigzag-shaped piece has been cut off and is placed at a distance. The piece gives associations to tapestry and traditional Nagorno-Karabakhi handicraft, but more importantly, if given a slight 'push' to the left, it will fit perfectly in with the rest-and replicate the Armenian flag.

Another result of the above-noted ambiguity was the long delay in adopting a constitution. Not until 10 December 2006 (exactly 15 years after the referendum on independence) was a constitution approved through a referendum.65 Article 1 sets out that NKR is 'a sovereign, democratic, rule-of-law based and social state'.66 Article 14.2 maintains that NKR citizenship is granted and rescinded according to relevant legislation. In practice, however, there is no separate Nagorno-Karabakhi citizenship as such, as the citizens of NKR all hold Armenian passports. These passports have the advantage of providing the Nagorno-Karabakhis with the opportunity to travel abroad, but a special code in the passport shows that they live in NKR and are not eligible for the same benefits and services as (other) Armenian citizens.

The absence of ethnic and religious cleavages in Nagorno-Karabakh is reflected in political life. In the first presidential elections, held in 1996, Robert Kocharyan, de facto leader of NKR since 1992 as Chairman of the State Defence Committee, became president. When Kocharyan was appointed Prime Minister of Armenia the following year, new elections had to be held. He was succeeded by his close ally, former minister of foreign affairs Arkadii Ghukasyan, who was re-elected in 2002. In 2007, Ghukasian's hand-picked successor, former head of the National Security Service, Bako Sahakyan, won the presidential election.67

63Interview with Kamo Ataian, NKR Minister of Education, Culture and Sports, Karabakhskii ekspress, 2006, p. 37.

64Authors' interview with Davit Babayan, professor of political science at Artsakh State University, Stepanakert, 12 September 2006; authors' interview with Deputy Foreign Minister Masis Mayilyan, Stepanakert, 12 September 2006.

65 According to the NKR Central Election Commission, $98.6 \%$ of the votes cast were in favour of the draft constitution. Turnout was $87 \%$ (available at: www.elections.nkr.am/eng/Rezultati referenduma.htm , accessed 14 February 2007).

66'Konstitutsiya Nagorno-Karabakhskoi Respubliki', available at: www.nkr.am/rus/Constitution.htm, accessed 10 January 2007. ${ }_{67}$ Sahakyan won $85 \%$ of the vote, with Deputy Foreign Minister Masis Mayilyan a distant second at $12 \%$. 
Thus, NKR has never experienced a turnover of power such as Abkhazia has.

Parliamentary elections were held in 1991, 1995, 2000, and 2005. In the first three

elections the electoral system was purely majoritarian, while in 2005 a mixed system

was introduced and one third of the seats were filled by party lists. This change did

not, however, strengthen party representation in the parliament: whereas almost one

third of the seats in the outgoing parliament were controlled by the vocal opposition

party ARF Dashnaksutyun (Hay Heghapokhakan Dashnaktsutium),68 only three of

the seats in the current parliament are held by the opposition (representing the ARF

Dashnaksutiun -Movement 88 bloc).69 Such near-unanimity in national politics can

have various explanations. It may reflect a high degree of satisfaction with the

regime in power, a siege mentality that encourages the population to close ranks

behind the powers that be, or it may indicate an undemocratic, authoritarian regime

that hampers the development of a truly pluralistic system. International

organisations like the OSCE do not, as a matter of principle, monitor elections in

unrecognised states, but observers from Armenia and other countries have been

present at elections, and no complaints of widespread fraud seem to have been

made.

Nagorno-Karabakhi civil-society spokespersons claim that there are few problems

with freedom of the press in NKR-indeed, NKR is hailed as better in this regard than

all other South Caucasian countries, including Armenia.70 The courts are considered a

greater difficulty, and it is claimed that their lack of independence is an Achilles' heel

of Nagorno-Karabakhi democracy. As for civil society, it may not be exactly

blossoming, but it is not repressed either. According to Naira Hayrumyan,

coordinator of the Karabakh Open Press Club, there are perhaps 150 registered

NGOs in NKR, of which only some 20 are currently active. Members of the diaspora

give little support to the building of civil society, preferring to put their money into

infrastructure projects, Hayrumyan claims.71

During perestroika, the Armenian national movement started as a campaign for unification between NKR and

Armenia. Today, only one small party in NKR (Armenia Our Home, Mer Tun' Hayastan) is openly arguing for unification, while all the others officially fight for recognition of NKR as a separate state. However, all

political parties know that the moment that such recognition is achieved, the state will be free to do what it wants with its independence-which includes being able to give it up.72

As regards South Ossetia, since the declaration of independence it has experienced a

population loss. Ethnic Ossetians fled to Russia to escape the fighting and destruction,

68The ARF Dashnaksutiun -Movement 88 bloc initially supported the government, but fell out with the Democratic Party (Artsakhi Demokratakan Kusaktsutyun) in 2004.

69The pro-presidential Democratic Party holds 12 seats and its ally Free Motherland (Azat Hayrenik) holds 10. The remaining eight seats are held by non-party loyalists.

70Authors' interview with Naira Hayrumyan, coordinator, Karabakh Open Press Club, Stepanakert, 12 September 2006.

71Authors' interview, Stepanakert, 12 September 2006.

72 To be sure, those pundits who predicted that Moldova would reunite with Romania as soon as the republic gained independence in 1991 were proven wrong. On the other hand, the chances that the Nagorno-Karabakhis will follow the political path of the Moldovans seem slim. 
while ethnic Georgians fled to other parts of Georgia. Although many South Ossetians have since returned, the total population of the Tskhinvali-controlled part of South Ossetia has probably fallen below $70,000.73$ On the other hand, there has been a trek of ethnic Ossetians out of Georgia proper, mainly during the first years of independence. Of the 99,000 Ossetians who lived in Tbilisi, Borjomi and other places in Georgia before the war, only about a third remain. 74 Those who fled, however, generally did not go to South Ossetia, which had little to offer in terms of security and welfare. The vast majority ended up in North Ossetia and other parts of Russia.

With the benefit of hindsight, official spokespersons in Tskhinvali today see the Shevardnadze years as a trail of lost opportunities when it comes to state-building and nation-building. 75 In this period the lack of international recognition was not felt as an acute problem, and the guard was lowered. When 'everything was going so well', there were also fewer expectations as to complete independence. At that time a solution might possibly have been found in some kind of confederate framework. Negotiations with the Georgian authorities were conducted, albeit sluggishly. But now, under Saakashvili, with independent statehood under threat, the determination to fight has been strengthened and the sense of nationhood has grown stronger.76 This determination was underscored by a second referendum on independence on 12 November 2006 (the first had been held on 19 January 1992). The official results expressed the will of a solidly unanimous and united nation: $99.9 \%$ supported independence from Georgia (Owen 2006).

At the same time, the ultimate aims of the independence struggle in South Ossetia remain just as ambiguous as in Nagorno-Karabakh. There is no concept of a separate South Ossetian nation and no desire to develop one. What is seen to exist is one Ossetian nation that is divided into two separate political units-South Ossetia, and the North Ossetian Republic in the Russian Federation. In the Soviet period, all Ossetians could still have a sense of living in one state-the USSR-even though they were subordinated to two different union republics. The enforced partition of the Ossetian nation took place only when Georgia declared its independence. The South Ossetians want to heal the partition and reunite the two halves of their nation. Independent statehood is seen as merely a means to this end, and will gladly be given up the moment it has been achieved. In symbolic nation-building this is illustrated by the fact that the flag and coat of arms of South Ossetia are identical to those of North Ossetia.

Since North Ossetia is a subject of the Russian Federation, reunification of Ossetia can take place only within the framework of this state. South Ossetia has several times appealed to the authorities in Moscow to clarify the procedures for being included in the Russian state. While waiting for an invitation to join, they pursue stepwise integration through contacts with local and regional leaders in Russia. One such 
example is the September 2006 initiative of Tskhinvali mayor Vadim Tskhovrebov and acting mayor of Volgograd Roland Kheryanov to create 'a Russian single civil space'. According to Tskhovrebov, South Ossetia has already, in effect, been within the civil space of the Russian Federation for some time: 'I am sure that the time has come to give this space the corresponding political and legal status'. 77 Tskhovrebov has already begun this integration at home: his office is adorned with portraits of both the South Ossetian president Eduard Kokoity and of Vladimir Putin, and his business card shows both the South Ossetian and the Russian coats of arms.78 Other steps of practical integration include the use of Russian rubles as currency and Russian passports as travel documents.79

According to Article 1.1 of the South Ossetian constitution,80 'The Republic of South Ossetia is a sovereign, democratic, rule-of-law based state'. Presidential elections have been held three times. In 2001, the incumbent, Lyudvig Chibirov, finished third in the presidential elections 81 and was replaced by former businessman Eduard Kokoity. The latter was re-elected in 2006 with a landslide victory: $98 \%$ of the voters cast their ballots for the incumbent (Owen 2006).

On the very same day as Kokoity was re-elected, however, alternative presidential elections as well as a referendum on relations with Georgia were held in the territories of South Ossetia that are currently under Georgian control. Here $94 \%$ voted for Dmitrii Sanakoev as president, and most voters also supported the idea of conducting talks with Georgia about joining a potential federation (Bartuzi 2006). While Tskhinvali denies the legitimacy of these alternative elections, it is a sore point that Sanakoev is a former prime minister of the South Ossetian republic who broke with Kokoity in 2001. Although neither election was officially recognised by Tbilisi, the alternative elections created the impression of an Ossetian nation that is divided not only geographically by the Caucasian mountains but also politically over the issue of secession.82 A further blow to Tskhinvali was President Saakashvili's decision in April 2007 to accept the Sanakoev administration as the provisional, pro-governmental government of South Ossetia with which Tbilisi should negotiate a settlement. The South Ossetian parliament consists of 33 members elected for five-year terms.83 Elections were held in 1990, 1994, 1999 and 2004. Currently there are three parties represented: the Communist Party (Kommunisticheskaya Partiya), Unity (Edinstvo) and the Popular Party (Narodnaya Partiya). The two former have strong links to their

77Nezavisimaya Gazeta, 12 September 2006.

78As observed 15 September 2006.

79ln August 2006, the South Ossetian authorities began to issue their own passports, but these are valid only within the borders of the republic.

80'Konstitutsiya Respubliki Yuzhnaya Osetiya', available at: http://cominf.org/2004/10/15/konstituciya_respubliki_yuzhnaya_osetiya.html, accessed 10 January 2007.

${ }_{81}$ Chibirov had been head of state since 1993-first as chairman of the parliament and then as president from 1996.

${ }_{82}$ At the same time, the notion that political allegiances in South Ossetia should follow almost exactly the tortuous line that separates Georgian and South Ossetian authorities is simply not credible, and the results of the double elections and double referenda clearly indicate that democratic standards on both sides leave something to be desired.

83'Konstitutsiya Respubliki Yuzhnaya Osetiya', available at: http://cominf.org/2004/10/15/konstituciya_respubliki_yuzhnaya_osetiya.html, accessed 10 January 2007. 
sister parties in Russia, CPRF and United Russia. Although there are some differences between them, these do not extend to the question of independence: all South Ossetian political parties support secession. As regards civil society, this seems less developed than in the two other quasi-states examined here.

Conclusion: comparison of state- and nation-building capabilities

Barry Bartmann (2004, p. 15) argues that in the modern world the legitimacy of states consists of two aspects: on the one hand, viability and survivability, that is, the capacity to fulfil the functions of statehood; on the other, the 'right' to a separate destiny. Legitimacy, then, has both a practical and a moral aspect. Virtually all studies of quasi-states have focused on the latter. This article has been devoted to the former. By virtue of continuing to exist one and a half decades after their unilateral secessions, the three quasi-states of the South Caucasus have demonstrated a capability to survive under adverse circumstances. Some observers have therefore concluded that they are quite strong.

The territorial separatists of the 1990s have become state-builders in the early 2000 s, creating de facto countries whose ability to field armies, control their own territory, educate their children, and maintain local economies is about as well developed as that of the recognised states of which they are still notionally a part. (King 2001, p. 525)

In contrast to this view, Dov Lynch sees the quasi-states as failing: 'They have the institutional fixtures of statehood, but they are not able to provide for its substance' (Lynch 2002, p. 841).

According to Kolstø (2006), the modal tendency of unrecognised quasi-states is weak state-building, and some strong structural reasons were indicated why this should be the case. Firstly, the war for independence was in all cases fought mainly or exclusively on the territory of the breakaway region, and material damage was massive. Secondly, the war in many cases led to a criminalisation of the economy. As Espen Barth Eide (1999) has pointed out,

While wars, blockades and exceptional situations are devastating for the majority, they create breeding ground for certain types of economic activity that proves particularly effective in the absence of order. The people that benefit from such activities see few reasons to support the re-establishment of effective public control.

Thirdly, quasi-states suffer from what Scott Pegg (1998, p. 43) has called 'the economic cost of non-recognition': the states from which they have seceded will often be able to impose an embargo on trade with the breakaway region, and foreign investors will be wary of dealing with the separatists, lest they find themselves barred from the normally larger market of the metropolitan state. Finally, since quasi-states are not officially recognised, no international conventions can be applied on their territory, and no effective monitoring by international organisations is possible. The resultant lack of transparency in these states can prove extremely attractive for criminal and other semilegal businesses.

Even so, on closer inspection we can detect clear differences in the state-building and nation-building capabilities of the three South Caucasian secessionist states. With 
regard to capacity for defence, border control, and control over territory, there is a clear hierarchy: Nagorno-Karabakh on top, Abkhazia in the middle and South Ossetia at the bottom. Also other aspects of 'hard' state-building-like economic development, the consolidation of state institutions, and the establishment of a permanent population-follow more or less the same order. To be sure, NKR until December 2006 lacked a constitution, whereas South Ossetia had adopted its constitution in 1993. However, much of the South Ossetian legislation was simply copied from Russian laws, with the word 'South Ossetia' substituted for 'Russia', as if by a 'search-and-replace' method. Tskhinvali has never given high priority to building a state, since the aim has been to join Russia as soon as possible.84 While Karabakhis also hope that their state will be a transient phenomenon, they have not neglected institution building to the same degree. Of the three cases examined here, the Abkhaz are perhaps most determined to establish a permanent independent state. According to some observers, no more than half of Abkhazia's population would wish to join Russia if they were given a choice, while the other half would opt to go it alone.85 With regard to ethnic and civil nation-building, we note that in all three quasi-states the moral and legal basis for secession is said to be the ethnic discrimination experienced in Georgia or Azerbaijan by the titular nationality. In all of them, the current demographic makeup is a result of forced migration through which the proportion of the titular nationality in the population has risen. Even so, in none of the states is there today a perfect match between the civic and the ethnic nation, as they define it. In Nagorno-Karabakh and in South Ossetia, the titular nation is an entity larger than the population of the breakaway republic, while in Abkhazia it is smaller. While the ethnic Abkhaz still do not constitute a majority in 'their' republic, this has not prevented the development of what appears to be a relatively vibrant democracy in Abkhazia. According to social philosophers such as John Stuart Mill (1859) and Robert Dahl (1971), pluralistic democracy will develop more readily in homogeneous societies than in divided ones. We found that, of the three cases,

Abkhazia exhibits the highest degree of openly expressed political diversity. In a statebuilding perspective, however, the strength of the Abkhaz democratic institutions cannot make up for the lack of the economic dynamism and ethnically-based unity shown by Nagorno-Karabakh.

If the hierarchy of state-building we have identified is correct, how can it best be explained? Clearly, size is not the determining factor: NKR has less than two thirds the population of the Republic of Abkhazia; South Ossetia, on the other hand, has about half the population of NKR. Also their former status in the hierarchy of Soviet national autonomous units does not seem to play a role. In the Soviet period, NKR and South Ossetia were merely autonomous oblasti, while Abkhazia enjoyed the status of autonomous republic. Also the avoidance of war destruction is a poor indicator of potential state-building. If anything, this factor stands in a reverse relationship to the hierarchy we believe to have observed. 
Among the factors that seem more important we find, firstly, the stance adopted by the challenger state. A strong and uncompromising challenger state facilitates independent state-building in the breakaway region, while a more accommodating attitude might impede it. The experience of South Ossetia is illustrative in this respect. In the assessment of South Ossetian officials themselves, the low degree of tension on the South Ossetian - Georgian border under Shevardnadze had the effect of retarding South Ossetian state-building efforts. As long as the South Ossetians had numerous relatives in Georgia proper and could freely go and visit them, it proved extremely difficult to muster support for a policy that might lead to the complete severance of such ties.

Such experiences may go some way in explaining the intransigence of many quasistates in bilateral negotiations with the metropolitan state. Secessionists will be extremely wary of falling into what they see as an 'accommodation trap', a slippery slope that leads to gradual and imperceptible reintegration. There is, for instance, no doubt that reopening the railway connections from Russia to Armenia over Abkhaz and Georgian territory could greatly boost the struggling Abkhaz economy, and the Georgians are very much in favour-provided that these connections can run by them on Abkhaz territory as well. Negotiations for a reopening of the railroad have so far failed to produce concrete results, and the Abkhaz authorities declare that the moment Georgia insists on establishing its own customs control posts on Abkhaz territory, they will break off negotiations immediately (Dzhodzhua 2006, p. 3). While this position might seem unyielding, the Abkhaz opposition nevertheless accuses the current administration of being dangerously cooperative and of 'putting economy before politics'. As evidence of this softness, they point to the fact that as a basis for the negotiations the Abkhaz side has accepted some maps of Abkhazia with Georgian toponyms (Troyanskii kon' 2006, p. 2).

A second important factor is the role of the patron state. All three South Caucasian quasi-states enjoy the backing of and are heavily dependent on an external patron, but the degree of support varies. As patron of Abkhazia and South Ossetia, the Russian Federation has vacillated between the role of partisan supporter of one side in the conflict and that of an 'honest broker'. This has caused some apprehension among its clients. The Abkhaz Minister of Foreign Affairs clearly sees Abkhazia as a pawn in a greater Russian Caucasian game; 86 and South Ossetian interviewees indicated that in case of renewed hostilities with Georgia they would be able to rely on wholehearted support only from North Ossetia,87 although this republic cannot fulfil the role of a serious external patron. By contrast, the Armenian backing of NKR is far more singleminded and consistent. Moreover, the NKR enjoys the support of a prosperous and generous overseas diaspora-an asset that the two other quasi-states cannot match.

University of Oslo

Norwegian Institute of International Affairs (NUPI), Oslo

86Authors' interview, Sukhumi, 7 September 2006.

${ }_{87}$ Various interviews with authors, Tskhinvali, 15 September 2006. 


\section{References}

Anjaparidze, Z. (2006) 'South Ossetia Peace Plans Smell of Gun Powder', Eurasia Daily Monitor, 3, 120.

Ayrapetyan, E. (2006) 'Strategiya vozrozhdeniya', Karabakhskii ekspress, pp. 2 - 3.

Baev, P. (1998) Russia's Policies in Secessionist Conflicts in Europe in the 1990s, Security Policy Library,

11 (Oslo, Norwegian Atlantic Committee).

Bahcheli, T., Bartmann, B. \& Srebrnik, H. (eds) (2004) De Facto States: The Quest for Sovereignty

(London, Routledge).

Baran, Z. \& de Waal, T. (2006) 'Abkhazia - Georgia, Kosovo - Serbia: Parallel Worlds?', debate at Open Democracy, available at: www.opendemocracy.net/democracy-caucasus/abkhazia_ serbia_3787.jsp, accessed 15 January 2007.

Bartmann, B. (2004) 'Political Realities and Legal Anomalies: Revisiting the Politics of International Recognition', in Bahcheli et al. (eds) (2004).

Bartuzi, W. (2006) 'Tbilisi Changes the Status Quo in the South Ossetian Conflict', EastWeek, 60. Chamagua, V. (2006) 'Vlasti Gruzii popali v sobstvennyi kapkan', Respublika Abkhaziya, 22-23

August.

Chirikba, V. (nd) 'Abkhazia: Economic and Political Situation and Perspectives', available at: www.abkhazia.org/chirikba19990411.html, accessed 16 December 2006.

Coppieters, B., Nodia, G. \& Anchabadze, Y. (eds) (1998) Georgians and Abkhazians: The Search for a Peace Settlement (Cologne, Bundesinstitut fu" $r$ Ostwissenschaftliche und Internationale Studien).

Cornell, S. (2000) Small Nations and Great Powers: A Study of Ethnopolitical Conflict in the Caucasus (London, Routledge).

Cornell, S. (2003) 'The Growing Threat of Transnational Crime', in Lynch, D. (ed.) (2003) The South Caucasus: A Challenge for the EU, Chaillot Papers 65 (Paris, European Union Institute for Security Studies).

Dahl, R.A. (1971) Polyarchy, Participation and Opposition (New Haven, Yale University Press). de Waal, T. (2003) Black Garden: Armenia and Azerbaijan Through Peace and War (New York, New York University Press).

Dzhodzhua, R. (2006) 'Vokrug problemy vozobnovleniya raboty Abkhazskoi zhelezhnoi dorogi', Grazhdanskoe obshchestvo, 57.

Eide, E.B. (1999) 'The Internal Security Challenge in Kosovo', paper prepared for UNA- USA/IAI Conference on 'Kosovo's Final Status', Rome, 12 - 14 December 1999, available at: www. unausa.org/site/pp.asp?c1/4fvKRI8MPJpF\&b1/4476109, accessed 15 January 2007.

Fuller, L. (2006) 'Georgia: Abkhaz Leader Unveils New Peace Plan', RFE/RL, available at: www.rferl.org/featuresarticle/2006/05/353edf04-1013-4e4f-8d94-e6c350fab88d.html, accessed 2 February 2007.

Herzig, E. \& Kurkchiyan, M. (eds) (2005) The Armenians: Past and Present in the Making of National Identity (London, RoutledgeCurzon).

Hewitt, G. (ed.) (1999) The Abkhazians: A Handbook (Richmond, Curzon Press).

Ivanova, M. (2006) 'Eto nasha Rodina. My vernems'ya v Abkhaziyu nasovsem', Nuzhnaya gazeta, 6 September.

KliP (2006) 'Sdelano v respublike mnogo, no predstoit sdelat' eshche bolshe', available at: http:// cominf.org/2006/12/26/jurijj_morozov_sdelano_v_respublike_mnogo_no_predstoit_sdelat_eshhe_ bolshe.html, accessed 20 January 2007.

King, C. (2001) 'The Benefits of Ethnic War: Understanding Eurasia's Unrecognized States', World

Politics, 53, 4.

Kolossov, V. \& O'Loughlin, J. (1999) 'Pseudo-States as Harbingers of a New Geopolitics: The Example of the Transdniestr Moldovan Republic (TMR)', in Newman, D. (ed.) (1999)

Boundaries, Territory and Post-Modernity (London, Frank Cass).

Kolstø, P. (2000) Political Construction Sites: Nation Building in Russia and the Post-Soviet States (Boulder, Westview Press). 
Kolstø, P. (2006) 'The Sustainability and Future of Unrecognized Quasi-states', Journal of Peace

Research, 43, 6.

Kolstø, P. \& Blakkisrud, H. (eds) (2004) Nation-building and Common Values in Russia (Lanham, Rowman and Littlefield).

Kolstø, P., Edemsky, A. \& Kalashnikova, N. (1993) 'The Dniester Conflict: Between Irrendentism and Separatism', Europe-Asia Studies, 45, 6.

Kolstø, P. \& Malgin, A. (1998) 'The Transnistrian Republic: A Case of Politicized Regionalism', Nationalities Papers, 26, 1, March.

Lynch, D. (2002) 'Separatist States and Post-Soviet Conflicts', International Affairs, 78, 4.

Lynch, D. (2004) Engaging Eurasia's Separatist States: Unresolved Conflicts and De Facto States

(Washington, DC, United States Institute of Peace Press).

Malysheva, D.B. (1996) Konflikty na Kavkaze: Regional'noe i mezhdunarodnoe izmerenie (Moscow, Institut mirovoi ekonomiki i mezhdunarodnykh otnoshenii RAN).

Mill, J.S. (1859) On Liberty (Indianapolis, Hackett) [reference is to the 1978 version].

Nagorno-Karabakhskaya (2006) Nagorno-Karabakhskaya respublika (Stepanakert, Antares).

Natsional'nyi sostav (1991) Natsional'nyi sostav naselniya SSSR (Moscow, Goskomstat SSSR).

Owen, E. (2006) 'South Ossetia: Where Memories of the Pre-conflict Era are Fading', Eurasia Insight, 17 November.

Pegg, S. (1998) International Society and the De Facto State (Aldershot, Ashgate).

Potier, T. (2001) Conflict in Nagorno-Karabakh, Abkhazia and South Ossetia: A Legal Appraisal (The Hague, Kluwer Law International).

Public International Law and Policy Group (2000) The Nagorno Karabagh Crisis: A Blueprint for

Resolution available at: www.nesl.edu/center/pubs/nagorno.pdf, accessed 22 October 2007.

Shul'gina, N. (2006) 'Vy-budushchee Abkhazii, vy nuzhny svoei strane', Respublika Abkhaziya, 26-

27 August.

Troyanskii kon' (2006) 'Troyanskii kon' “Konsortsium”', Forum, 20, 55.

Zakon (2004) 'Zakon Respubliki Abkhaziya “O gosudarstevennom byudzhete na 2004 god”', Sbornik zakonodatel'nykh aktov Respubliki Abkhaziya (Sukhum, Otdel ekonomiki i prava Administratsii

Prezidenta Respubliki Abkhaziya).

Zayavlenie (2006) 'Zayavlenie predstavitelei grazhdanskogo obshchestva Abkhazii', Grazhdanskoe obshchestvo, 64 